\title{
Youths and National Development in The Gambia
}

Loveday Enyinnaya Ogbuleke

Department of Peace and Conflict Resolution Studies, College of Arts, Law, Administration and Management Sciences (CALAMS), Legacy University, The Gambia. Email: ogbuleke2013@gmail.com

Copyright: (02021 Loveday Enyinnaya Ogbuleke. This is an open access article distributed under the terms of the Creative Commons Attribution License, which permits unrestricted use, distribution, and reproduction in any medium, provided the original author and source are credited.

\section{ABSTRACT}

It is obvious to postulate that there is a linkage between youth and national development. Due to the challenges facing youths has been attributed to the lack of a comprehensive policy to provide a blueprint for youths. Therefore, this study interrogates the role of youths on national development in the Gambia and the intercourse is not only symbiotically connected; but, one depends on the other for its sustenance. The study is descriptive and data obtained from secondary and primary sources. The findings in the study revealed that hostile political environment, institutional settings and public policies among others has been major setback, however, the Gambia youths are still pertinent to national development due to self-help projects in various local governments in Gambia especially projects that involve trade, commerce, small and medium term enterprises and agriculture. Also, on religion awareness, conflict resolution and security, like the Youth Crime Watch The Gambia (YCWG) engage the necessary measures to address all vulnerabilities that may tend to destabilize the country. Since the wheel of development of any country lies on the shoulder of how productive and creative the youthful populations are with over $63.55 \%$ of 2.2 million populations. So, therefore, this quantum of population is a great asset for the Gambian state if they are harnessed and utilized in the right direction. The Gambia National Development Plan (2018-2021), constitution and policies should be pluralistic for youth representation, and just in their treatment of the Gambian citizens.

Keywords: Youth, youth empowerment, Development, National development, The Gambia.

\section{Introduction}

Governments all over the world exist to ensure the well-being of the citizenry which in turn have a corresponding impact in driving growth and sustainable development. This underlies why the citizenry crave for programmes that would drive their youth's aspirations for improved living conditions and development. According to the United Nations (2010), Africa's 2011 population was estimated at 1.05 billion and is expected to double by 2050 . Africa is the youngest continent in the world: About 70 percent of its population is 30 years of age or younger (cited in Odoh and Eme, 2014). In advancing these, provide opportunities for the continent's more than 226 million youths so that they can have decent lives and contribute to the economic development of their countries. This can be achieved through youth's empowerment.

According to the Concise Oxford Dictionary of Current English, youths are described as the period between childhood and full manhood. It is the period between childhood and adulthood, described as the physical period and psychological development from the beginning of puberty to maturity and early adulthood. In Liberia, one is considered youth when he/she is between the ages of 15-35 years according to "The Revised National Youth Policy (2009-2017)". Youths become dynamic in actions and play distinct roles in building a nation. Youths must have the ability to make choices that support the pursuit of educational goals and the development of life skills necessary for national development (Cited in Gray, 2018).

National development refers to the ability of a nation to improve the lives of its citizens. The measures taken to bring about this improvement may be material, such as an increase in the nation's Gross Domestic Product (GDP) or social such as literacy rates, availability of affordable healthcare and housing. The notion of national 
development has become a major preoccupation of most individuals, communities or nations particularly in the developing world. It affects not only human aspiration but also the fundamental issue of national survival due to its capacity to induce growth, progress, modernization and social transformation.

One of the ways that nations use youth to enhance their national development is through the empowerment programmes which are closer to the population. The objective of the creation of the empowerment programmes is to bring governance closer to the youths to enable them realize their potentials that could have the desired impact on national development. For instance, the US government over the years, the White House Council for Community Solutions has developed an Employer Toolkit, which provides tools for employers helping them engage in soft skills development and work-ready skills training for youth as well as a toolkit helping employers design “earning-and-learn” programs for youth (Jacobs, 2014).

In Kenya, Zedekia and Michael (2016) noted that the youth are often victims of conflict, and a disturbing dimension of conflict is the growing role of youth in fomenting conflict, as tools or instruments. While the role of young people as peace agents is a global concern, one particularly disturbing dimension is the role of youth in 2007-2008 post-election violence in Kenya. This phenomenon started with Kenya youth parliament; but it has developed into a grim reality and a formidable political force in Kenya (Ibid). Conversely, the size, energy, enthusiasm, innovation and dynamism of youths are assets that can be harnessed for Africa's development with appropriate policies that deal adequately with the issues facing them. This is in a bid to encourage youth empowerment at all ramification level for national development.

Gambia is one of Africa's smallest countries and, unlike many of its West Africa neighbours enjoyed long spells of stability since its independence barely interrupted with few hitches. The Gambian youthful population with 58\% of the population is less than 24 or within this age bracket. This trend is likely to continue due to a high fertility rate (nearly 5.67 children per in 2015) and a declining mortality rate. As a result, Gambia as a Nation has invested in its Youth for sustainable development by ensuring that policy takes into account the critical issues concerning youth. Although the elevated awareness of the challenges confronting Gambian youths noted by previous studies, Gambia still do not seem to have developed comprehensive and effective policies to deal with the issues facing this large and growing segment of the Gambian population or to have in place a means to assess the progress made. According to the Gambian Strategic Plans 2018-2020 allied with UNESCO Visions, the large young population generates an important youthful workforce. While employments help to increase considerably economic empowerment, many of young people lack the skills or access to the necessary skills-upgrading opportunities to enter the labour market. This has resulted to alternative means of subsistence including irregular migrations, and indecent jobs.

Regrettably, after independence in the 1960s, the Government and other voluntary youth agencies did not target the youths in the development agenda. The Gambian Government started the National Youth Policy in 1990s and has supported it to date is to enhance training and employment opportunities for young people (Sylvia and Gareth, 2005). Most other youth programmes are largely social and recreational in nature. In addition, they are urban-based. Although, the current Government has taken a keen interest in youth issues in its efforts for national 
integration, but the unemployment, poverty, youth illiteracy continued to pose grave challenges to the youth population in the Gambia. The Gambia's National Development Plan (2018-2021), however emphasise the need to reaping the demographic dividend through an empowered youth and making the private sector the engine of growth, transformation, and job creation, while acknowledging the efforts made to address unemployment among the youths, warned that the problem would in future loom large.

Efforts to initiate youth development programmes have been made in other subsequent policy documents, such as the Youth Empowerment Project (YEP) enhancing employability and self-employment opportunities of youth, with a focus on vocational training and the creation of micro and small-sized enterprises (MSMEs), and by creating and improving employment opportunities in selected sectors through value addition and internationalization. But, despite these efforts, as well as an increase in the number of agencies dealing with the youths, problems affecting young people have continued. This situation has been attributed to the lack of a comprehensive policy to provide a blueprint for youths.

However, the following constraints have hampered their effectiveness in achieving their objectives: i. Pressure from the high population growth: The high population growth, currently standing at 3.2\% (2018), while youths make up $63.55 \%$ of 2.2 million population (Bureau of Statistics) putting pressure on available resources as the number of young people keeps on rising. ii. Lack of appropriate skills: The 6-3-3-4 education system and tertiary training institutions continue to release thousands of graduates, who are neither properly equipped for entry into the labour market nor possess the necessary life skills. iii. Unclear and uncoordinated youth policies and programmes: While a number of Government Ministries and youths organisations have their own programmes and sectoral youths policies, lack of a national youth policy and effective co-ordination mechanisms hamper their effectiveness. iv. Resource Constraints: Most of the youth programmes, run by both the Government and non- governmental agencies lack adequate funds and equipment, which limits their success. v. Low status given to youths: Existing structures and prevailing attitudes do not provide an enabling environment for youths participation in decision-making, planning and implementation processes

Given the above context, this study aims to unpack the nexus between youths and national development in the Gambia by assessing the role of youths in the Gambia polity and the effect on national lives. The authors also bring to fore the perceived challenges facing youth's viz-a-viz national development in the Gambia, and the extent to which these challenges are being addressed by the Banjul government.

\section{Objectives of the Research}

The main objective of the study is to assess how youths engage in national development and the extent which it have affected socio-economic development of the nation. Specific objectives are as follows:

- To establish the relationship between youth and national development.

- To ascertain the perceived challenges facing youths on national development in the Gambia.

- To identify the role youths played on national development in the Gambia. 


\section{Research Method}

This study conducted extensive secondary research which involves rigorous library search such as test books, newspapers, journals, magazines, the internet, periodicals, and reports on youths and national development in the Gambia. However, some interviews were conducted on some youth's base on close ended questions to ascertain the various roles they played and challenges facing youths in the Gambia since 2016. This study is past and contemporary in nature and, as such documentary method of the collection was employed. The descriptive and analytical method of data analysis was employed as it enables a better and clearer understanding of the past and the present issues. These provided information on frequency youth played on national development in the Gambia.

\section{Justification for the Study}

The study of this nature becomes imperative in that it is conceived to serve as an eye opener to the government, leaders, policy makers who might be able to ascertain the significance of youth on national development, and the study also have the potential of serving as a guide to researchers who might be working on the areas of deficiencies of youths in the Gambia in order to improve on youth participations with a view to having a sustainable national development.

The study will stimulate further research on the subject. It is also expected to add to the existing body of knowledge on role of youth in the national development and could be of assistance to future researchers in related areas of study.

\section{The Nexus between Youth and National Development: A Discourse}

There is no universal definition of the youth population. "Youths" is traditionally defined as a period of transition from childhood to adulthood. In the African Youths Report 2009 (hereafter, the AYR) (UNECA 2009), "youths" are defined as people between 15 and 39 years of age. However, several African countries define their youth population differently. For example, Ghana, Tanzania and South Africa define the youth population as those between 15 and 35 years of age; Gambia and Swaziland define it as those between 15 and 30 years; and Botswana and Mauritius define it as those between 14 and 25 years.

On the other hand, the term national development is a term that refers to a sustainable growth and development of a nation to a more desirable one. Going by the definition, it is seen that all citizens are to be involved in building or developing a nation. Thus, the involvement of youth in national development is a must. In fact, youths play one of the most important roles in nation building. National development is people oriented and its success is evaluated in terms of the impact it has had in improving the lot of the masses. In defining the concept, the Third National Development plan of 1980says; True development must mean the development of man, the unfolding and realization of his creative potentials, enabling him to improve his material conditions of living through the use of resources available to him. It is a process by which personality is enhanced, and it is that enhanced personality creative, organized and disciplined-which is the moving force behind the labour market and socioeconomic transformation of any society (FGN, 1980). In the same vein, Jacobs (2014) aptly believes that institutional settings and public policies influencing youth labour market outcomes is the area of activation measures and active labour 
market policies. The study points out that the measures appear especially relevant because they are typically implemented within a given set of institutional and economic constraints and are thus independent of broad and comprehensive structural reforms. The role of activation policies and active labour market policy programmes in general has been a core pillar of many governments' efforts to promote youth labour market integration, whose action and inaction can develop or destroy the hegemonies/fabrics of their society (ibid). The study therefore, concludes that if investing appropriately in today's programmes so that service providers can truly meet the needs of their youths is critical to paving the way to a vibrant labour market for the next generation of American workers for national development. Hence, it is suitable for this study.

According to Onabajo and M'Bayo (2009), national development should be man oriented and not institution oriented, that is, individually in collectiveness and not individual. To Elugbe, (1994), 'national development refers among other things, to the growth of the nation in terms of unity, education, economic well-being and mass participation in government. Ogbuleke (2019) point out that the concept of national development is an extensive range of concerns in the potentiality and life of the youth of a nation In summary development entails the provisions of all the necessary materials and equipment that will guarantee that man in every society make a living and essence out of life. These definitions cove some of the desired application of youth empowerment and provide the linkage with national development. Besides, it is related to the development of the nation. This view is suitable for this study and therefore adopted.

Anaeto and Anaeto (2010) citing Todaro and Smith (2003), identified three objectives of development which are; 1. Increase availability and widen the distribution of basic life sustaining goods such as food, shelter, health and protection. 2. To raise levels of living in addition to higher incomes, the provision of more jobs, better education, and greater attention to cultural and human values, all of which will serve not only to enhance material well-being but also to generate greater individual and national self-esteem and 3. To expand the range of economic and social choices available to individuals and nation by freeing them from servitude and dependence, not only in relation to other people and nation states but also to the forces of ignorance and human misery.

Development is the socio-cultural, political, economic and the spiritual wellbeing of a society. In a truly developed state there is assurance of good quality of life, exercise of all human rights, and freedom to participate in the democratic process. From the foregoing, development implies enhanced quality of life, equity and justice, as it takes into consideration the wellbeing, growth and advancement of individuals within the society. This view identifies some elements of national development as well as the area of public affairs the elements could be applied. However, it fails to take into account the attributes of youths. Hence, it is not inclusive enough for this study.

Therefore, this study agrees that ignoring maximum commitment and engagement of youths on national development today will have dire consequences in the nearest future of the country. To better understand how to move the youths forward towards national development, there must be a careful examination of rationale for expanding the youth's frontier for active participation in national development (Gray, 2018). If youths are greatly involved in national development, it gives a clear picture that their potentials as change agents in mostly civil society are being highly recognized. Youths have a greater space in national development that must be consciously 
occupied by them, for national development does not only involves the implementation of political and economic policies and action programs that will improve the lives of the ordinary citizenry, but also recognizing the values and other aspects of the state that would act as a national developer to bind the people. Gray's view meets the requirement for this study and is therefore adopted.

\section{Youth Empowerment in The Gambia: The Perceived Challenges}

Despite making up more than half of the population in many countries, young people (ages 13/15/18-30) often find themselves marginalized from mainstream politics and decision making. They struggle to gain the respect of public officials and are seen as lacking the skills and experience to engage in political activity and lead positive change in their communities. This exclusion, combined with limited educational and economic opportunities, can leave young people both idle and frustrated with the status quo. Youth are the main stakeholders, policy makers and a major resource group playing an important role in taking up responsibilities, revolutionizing the other stakeholders, acting as a catalyst for bringing about change. They are leaders even now in their own right; hence, the word future is misplaced by those who refer the youth as future leaders. The socioeconomic and political environment in Gambia poses a great challenge to the youths. Economic and social statistics present a somber picture that leaves much to be desired. Almost half a century after flag independence, the economy continues relies primarily on agriculture, tourism and inflows of remittances. This is partly because the country has not been able to create an environment for high value added economic activities.

Action Aid's interviews suggest that the low agricultural production and productivity: the youth in the Gambia are migrating out of agriculture. Increasingly they have no incentive to remain or go back to the sector. While it is accepted that agriculture presents probably the best opportunity for increasing employment and reducing poverty, the challenge is that it largely remains a rural activity with the more educated youth more likely not to take up agriculture as career UNDP, 2014). There is low domestic capital formation and declining direct foreign investment, with the exemption of agricultural sector, until recently very heavy indebtedness, high unemployment and the informalisation of the economy where the majority of its people live in poverty. According to the World Bank, the latest value from 2018 is 2.02 compare to 7.8 percent in 2006. This implies that the rate of FDI in the Gambia is declining.

In the same vein, economic factors affects majority of young people. Most youths are not adequately provided with material resources for instance, they do not have own housing, and some are forced to rely on the financial assistance of parents (interview; Goode, 2020). The desire to get an education often keep them from entering the work force earlier and a lack of experience and knowledge at the right age prevents them from getting high-paying jobs. Goode maintains that lack of education due to financial status, job opportunities, and lack of projects that youths can participate, discrimination of youth in involvement of self-business from both family and the society in the Gambia (ibid). Gambia lacks basic social and physical infrastructure.

As a result, most people on the country have no access to basic services such as potable water, electricity, good sanitation, roads and healthcare. All of this is coupled with a high illiteracy rate, especially among youths and women (Interview; Goode, 2020). The lack of access to basic medical care occurs against a backdrop of ravaging 
diseases; a situation which has become exacerbated with the advent of the diabetes, hypertension, and HIV/AIDS epidemic (ibid). According to Mary Ikande, socio-cultural problems of young people are related to ideological, spiritual and moral areas of their life: lack of ideological and socio-cultural identification of youths; the destruction of the mechanism for spiritual continuity of generations due to the general disintegration of culture, the death of traditional values and traditional forms of social morality; a decrease in the interest of young people in the local culture, history, traditions; a decline in the prestige of education as a form of personal self-realization; low activity of youths in solving national, regional and local problems (Ikande, 2018).

The country's underdevelopment has been reinforced by authoritarianism, political instability, ethnic and religious conflicts in the last decade. This and more was factually captured by Ibrahim Camara that palpable mismanagement is marked by exclusion of the people from governance, non-accountability of public officials, lack of transparency in decision-making, electoral fraud and the colonialization and personalization of the state and national resources by the political elite. This situation presents particular challenges for the Gambian youths (Interview; Camara, 2020).

There are several reasons why youths could become an integral part of Africa's economic growth and development. First, they tend to be more educated than their older cohorts. Therefore, they can better absorb new technologies and ideas and adapt them to the African environment. Second, they tend to take more risks than their older counterparts. Finally, they are more likely to challenge certain norms and sociopolitical processes that may be hindering economic development. The consequences of not fully developing and harnessing youth's potential could leads to significant economic losses, armed conflict, and political and social upheaval and instability as demonstrated recently by the Arab Spring. Therefore, youths are more likely to become frustrated because of legitimate grievances, including a lack of employment opportunities, low educational attainment, little participation in decision making and low social mobility. In this volatile context, greedy and opportunistic politicians could even exploit these grievances by involving these frustrated youths in violent overthrows of legitimate governments creating massive instabilities that could limit the economic growth of Africa's countries (Collier and Hoeffler 2004).

According to the Gambian Appraisal Report (1999) the large proportion of the young people are illiterate and unskilled, particularly girls, and youths from rural areas and as a result cannot find employment in the lucrative tourist sector. Pupils usually dropout of school between grades $1-4$, before they have acquired a significant level of education, primarily due to lack of school fees. They therefore tend to revert to illiteracy after several years out of school. This also find in Camara Bintu position in which she has to dropout from school at grade 9 since 2018 and end up selling vegetables at Serrekunda Market due to lack of financial support from her parents (Bintu; interview (2020).

\section{Youths in The Gambia: Spectators or Participators in National Development Initiatives}

The term national development is usually used to refer to a constructive process of engaging all citizens in building social cohesion, economic prosperity and political stability in a nation in an inclusive and democratic way. The role of youths in Gambia's development cannot be overemphasized. Youths could be a source of labour inputs as well 
as human capital in production, which would improve total factor productivity in a region of the world where capital formation is limited. When employed, youths could be a reliable source of demand for the economy through their consumption activities. In addition, the youths of Gambia could be critical for the development of a new class of entrepreneurs that Gambian districts need to prosper, because youth are not only the leaders of tomorrow, but also the partners of today.

On the area of human capital development which is the knowledge, skills, and competence, as well as other characteristics inherent in individuals. Since human capital is understood to be the stock of abilities, knowledge, skills, motivations and competencies embodied in a person, its formation is similar to the accumulation of physical or financial capital and requires diversion of funds from current consumption in order to obtain additional income in the future (Mark, Indira and Aliya, 2018). Africa has an opportunity to harness a "demographic dividend": With the projection that most countries in Africa will have more working-age adults per child in 2030 than in 2006, there will be a large workforce supporting fewer children and the elderly.

Consequently, this trend would result in a lower dependency burden, freeing up resources for development; see, for example, Ashford (2007). Almost half of the world's population is under age 25. Although youths between ages 15 and 24 are in greatest need of sexual and reproductive health services, those who are younger will quickly come of age and share these same needs. Providing youths with access to reproductive health education, services where they are welcomed, and accurate and comprehensive information will empower them to make healthy decisions. According to human capital theory, Dike (2012), argues that economic prosperity and progress of a nation depends precariously on the stock of its physical and human capital. Furthermore, human capital theory posits that formal education is greatly instrumental to improving the productive capacity of an individual worker.

However, since wars begin in the minds of men, it is the minds of men that the defences of peace must be constructed (UNESCO Constitution, 1945). Therefore, UN Security Council Resolution 2250 adopted in 2015, specifically calling on Member States to support local youth peace initiatives and empower youth in peace building and conflict resolution. In the Gambia, Sainey F Manneh maintains that contribution of youths in peace building is partly positive and negative. The low level of understanding of democracy among the youths turns them to be radical and violence. For instance, the post-election heated up with provocative violence which took place in Faraba and Gunjur youths lost their lives (Interview; Manney, 2020). Thus inclined youths organizations being in the forefront trying to sensitize communal on matters related to peace and coexistence (ibid).

As Gambia hosted the 10th anniversary celebration of the Africa Youth Charter (hereafter referred to as the Charter). Those celebrations provided AU Member States a unique opportunity to take stock of progress made in specifically implementing provisions of the Youth Charter, as well as broadly reflecting on the challenges of youth development in the continent, and more importantly, how best to collectively address those challenges, particularly in the areas of peace and security, in order to create a conducive environment for the youth to explore their full potentials. On that occasion, UNESCO, at the request of the AU, organized a 3-day training workshop on youth, peace and security, covering a range of topics, including violent extremism, gender equality, global citizenship, and designed to equip the young participants with the skills necessary to take action to effect positive change in their 
countries. It was therefore did not come as an entire surprise that when the opportunity availed itself, young Gambians took advantage and led the way in bringing change to their country. This is no mean feat, and hence there are lessons the continent can learn from that.

The aforementioned acknowledges the role of the youths in the peace and security of a nation or state. According to Isah Babayo, youths can play an active role in fostering peace by forming new programmes of peace missionaries and NGOs to network at the grassroots, concentrating on value education and spiritual renewal among children in Gambia. In the area of ethnic development, the youths of different ethnic groups can forge links between cultural minorities to share values, culture and tradition handed down from generation to generation (Babayo, 2017).

In the areas of training and retraining the youths on capacity building, over 30 youth leaders from different youth organizations participated in a four-day workshop on peace building, crime prevention and violence at the Tango Hall in Kanifing, which was organized by the Youth Crime Watch The Gambia (YCWG) on needs to engage the necessary measures to address all vulnerabilities that may ted to destabilize the country (cited in Ceesay, 2018).

Furthermore, in most rural areas in Gambia, various types of community based organizations exist. But the thriving organizations now are the ones formed by youths. In all parts of Gambia, youths community based organizations have been in existence. It has also emerged especially among the Muslim and Christian based communities. Efforts are being made to encourage the Youths Muslim to integrate into the formation of youths based community organizations. But the essence of the formation of the Youths community based organization is to supplement government efforts in community development projects. These organizations are the closest to the people at the grassroots level, because the organizations are formed by the members of the community themselves (Ayuba, 2012).

In an effort to accelerate rural development through youths participation cannot be over emphasized as youths are deeply involved in self-help projects in various local governments in Gambia especially projects that involve Trade, Commerce, Home Economics, Small and Medium Term Enterprises and Agriculture (Aminu, 2012). He further classified self-help projects into two: Government Aided Projects (GAP) and Non-Government Aided Projects (NGAP). Government aid projects are those executed with the assistance of the government in either finance or material resources while non-government aid projects are those executed solely with collective effort of community members. Over the years, youths have realized the importance of self-help projects in improving the way of life and living standards of their communities for provision of agriculture in enhancing food self-sufficiency in the Gambia (Interview; Umukoro, 2020).

In Mbagwu, Mannir, Ewelum, and Ezema (2016), findings revealed a number of constraints to youth involvement in self-help development projects. Respondents agreed to all the item options as constraints. Evidence from the pilot study conducted by the researchers agrees with the findings especially on the issue of youths not given a free hand to be involved in community development projects. Some youths, who were brainstormed by the researchers in the communities studied, testified that they were never carried along because their people felt that they are not matured to be involved in solving community problems. This is in line with Hmosillo (2012) who succinctly observed that most community leaders do not see the need for helping youths to begin their early transition from 
student to adult member of the community and as such adults make decisions for them and exert them over the youths. Over the years, youth participation is not only vital due to the civic rights they possess but it is very much needed due to the fact that young people would be the torch bearers in the future and so need to be involved today to enhance an easy process of transition from one generation to another. Thus, the role of youths in contemporary political participation and development, according to Christina Boutros, eligibility for national parliament starts at 25 years old or older in a third of all countries. About 1.6 percent of parliamentarians around the world are in their twenties. Young people between the ages of 15 and 25 constitute a fifth of the world's population, according to UN Youth (Boutros, 2016).

For instance, what transpired in the Gambia sends a clear message that young people across the world, and certainly in Africa, are increasingly becoming determined to lead a revolution that would forever transform their countries for the better, and leaders who refuse to yield to their demands, do so at their own peril. The younger generation of Gambians, a majority demographic by most measures, bears some of the most difficult burdens of the country's political transition, in myriad ways. Sainey F Manneh however, reveals that youths play a crucial role in using the social media like WhatsApp, Facebook etc. to campaign and educate people about politics and illegal doing of the former president. And also lots of youths were also involved with the electoral commission to serve as polling agents. Importantly youths in their large numbers vote during 2016 general election because of the promises given to them by the coalition (Interview; Manneh, 2020).

Consequently, in early February, 2017, Gambians from all walks of life streamed onto the streets of Banjul, the capital city, to triumphantly welcome home their new president, Adama Barrow, who, a few days earlier had been sworn into office, in neighbouring Senegal, as only the 3rd President of the Republic, in the country's political history. Barrow's return home was preceded by departure from the country, a few days earlier by one-time military dictator and strongman, Yayah Jammeh, after mounting domestic and external pressure on him to step down and hand over power to his successor, following weeks of recalcitrance on his part. For 22 years, Jammeh had presided over the destiny of Gambia and Gambians, ruling the tiny West African state as his personal fiefdom, with significant human toll on citizens.

According to Mamadou Faye in his study on "African youth Integration in politics" Intriguingly, the continuous participation of the African youth in major political transformation processes on the continent has not translated into political activity with regards to participation in elections, involvement in political decision-making or holding representative offices. African youths are generally not well represented by their public officials and a wave of political apathy has been the result, harming the prospect for improvements in the future. Pattern

To back aforementioned, United Nations (2015) reveals that in 2015, 226 million youth aged 15-24 lived in Africa, accounting for 19 per cent of the global youth population. By 2030, it is projected that the number of youth in Africa will have increased by 42 per cent. Africa's youth population is expected to continue to grow throughout the remainder of the 21 st century, more than doubling from current levels by 2055 (ibid).

Finally, given their vulnerability, the youth has the greater responsibility to promote peace, security, stability and national unity. Through their political education and public enlightenment campaign, through their policy 
advocacy, and their active involvement in the electoral process, they can build bridges of understanding across ethnic groups, across political affiliations and religious divide. Democracy and good governance can only be nurtured and sustained in an environment of peace, security and stability. Where these are lacking, it is not only democracy and good governance that suffer, but also social progress and the future of the youths is seriously compromised (Suleiman, 2006).

\section{Concluding Remarks}

In the light of the foregoing, the crucial issue of creating an enabling environment for the youths to bring their productive capacity and resourcefulness to bear on the political and developmental process should be accorded priority attention. Given the right climate therefore, the following are considered as the role-expectation of Gambian youths in the political and developmental process (Suleiman, 2006). First, the youths should parade itself as agents of political socialization. By political socialization, we mean the way in which political values are formed and the political culture is defused in the society. This socialization process ultimately determines how individuals form their political attitudes, and thus, collectively, how citizens form their political culture.

In Gambia today, the level of political culture is not sufficient enough to support our democracy. No thanks to more than two decades of military dictatorship during which the civil society was considerably militarized and civic engagement perverted (Osha, 2000). Studies have shown that the youth often provides the manpower requirements for general elections. Rather than succumb to the unwholesome man oeuvres of selfish and bankrupt politicians to pervert the process of elections, by way of hugger and rigging, the youths should exhibit good conscience and insist on due process and fair play. We have in Gambia also, an array of youth organizations with diverse and varied interest. They can begin to explore the political space to influence the decision-making process. Recent studies have proved that: Unless young people are consulted and involved in the design of developmental strategies they are not necessarily going to be youths-relevant or accurately factor in the contribution of youths to national developmental process.

\section{Declarations}

\section{Source of Funding}

This research did not receive any specific grant from funding agencies in the public, commercial, or not-for-profit sectors.

\section{Competing Interests Statement}

The author declares no competing financial, professional and personal interests.

\section{Ethical Approval}

Not applicable.

\section{Consent for publication}

Author declares that he/she consented for the publication of this research work. 


\section{References}

Abdalla H (2017), "Africa's youth and prospects for inclusive development; regional situation analysis report" https://www.ohchr.org/Documents/Issues/Youth/UNEconomicCommissionAfrica.pdf.

Adamu, A.(2003), "Youths and Development in Nigeria" Being a paper presented at National Congress of the National Youths Council of Nigeria held at Abacha Youths Centre, Lafia, Nigeria.

Ademiluka (1999), "Religious Extremism and the Learning Process" in I.T. Ogunye, S. Jegede and E. Akinsola (eds) Citadels of Violence. Lagos: CDHR.

African Union. (2006), African Youths Charter. Adopted by the Seventh Ordinary Session of the Assembly, Banjul, Gambia, July 2.

Aiyede, R.E. (nd), The State, Values and Development: Towards Re-orientating the Nigerian Youths for Positive Leadership.

Almond, G; Bingham, G; Powel, Jr.; Strom, K; Dalton, R.J. (2004), Comparative Politics Today, Pearson Education, Inc., Singapore.

Aminu AA (2012), "Youths and Community Development in Nigeria" Journal of Educational and Social Research Vol. 2 (7) October 2012.

Anugwom E. E and Anugwom K (2018), "Beyond Morality: Assessment of the Capacity of Faith-based Organizations (FBOS) in Responding to the HIV/AIDS Challenge in South-eastern Nigeria” Iran J Public Health. 2018 Jan; 47(1).

Babayo I (2017), "Youth as an agent of peace in Nigeria" http://www.yourcommonwealth.org/social-development/ peace -building/youth- as-an- agent- of-peace-in- nigeria/.

Ceesay Y (2018), "Youth Crime watch trains Youth Leaders n Peace building and Crime Prevention" The Point Newsletter.

Commonwealth Secretariat (2007), 'Plan of Action for Youths Empowerment 2007-2015'; London: Commonwealth Secretariat.

Eberly D. J., and Kielsmeier, J. C. (1991), National Youths Service: A Democratic Institution for the $21^{\text {st }}$ Editorial Comment, (2002), Three Years of Democracy, Nigerian Tribune, 1, 10.

Elisabeth Jacobs (2014), “Twelve Ways to Fix the Youth Unemployment Crisis" Governance Studies, the Brookings Institution 1775 Massachusetts Ave., NW Washington, DC 20036.

Elugbe, B.O (1994). National Language and National Development in Language and Polity, Government of The Gambia, The Gambia National Development Plan, PAGE II, 2017-2020, Draft.

Gray AG (2018), “The Role of Youths in National Development” https://www.thenigerianvoice.com/news/272496 /the -role-of-youths-in-national-development.html. 
Hermosillo, L. (2012). Community Leadership. Retrieved June 20, 2015, from http://ucpsarnet. igboprojects.org/ community leadership.

Human Rights Watch. (2005), "Youths, Poverty and Blood: The Legacy of West African Regional Warriors." Human Rights Watch 17, no. 5. IIED (International Institute for Environment and Development). 2011. Program 64: Participatory Learning and Action: Young Citizens: Youths and Participatory Governance in Africa. London: Institute for Development studies.

Ikande M (2018), “Challenges facing Youth Empowerment in Nigeria” https://www.legit.ng/1124065-challenges -facing-youth-empowerment-nigeria.html.

ILO (International Labor Organization). (2002), Decent Work and the Informal Sector. Report of the Director-General, International Labor Conference, 90th Session, Report VI. Geneva: International Labor Organization.

Kenya Ministry of State and Youths Affairs. (2007), Strategic Plan, 2007-2012. Nairobi: Government of Kenya. Mark W, Indira K and Aliya K (2018), “The role of education in realizing youths' human capital: social philosophical analysis” Ensaio: aval. pol. públ. Educ., Rio de Janeiro, v.26, n.100, p. 968-985, 2018.

Mbagwu, F. O.1, Mannir, A, Ewelum, J. N and Ezema, M. C (2016), "Youths Involvement in Self-Help Community Development Projects (SHCDPs) in Nsukka, Enugu State, Nigeria" Published by Canadian Center of Science and Education, Review of European Studies; Vol. 8, No. 4; 2016.

National Youths Policy (2001) - Federal Government Press, Lagos, Nigeria.

Newsweek Magazine (1981), Youths and Nation Building, October 15th p.15.

Nigerian Population Commission (2006), Population Commission Press, Abuja, Nigeria.

Ogbuleke LE (2019), "The Myth of the Secular Nigerian State and National Development" Middle East Journal of Applied Science \& Technology, Volume 2, Issue 3, Pages 01-10.

Onyekpe, N. (2007), Managing youths at election. The Constitution: A Journal of Constitutional Development 7 (1): 76-87.

p.28, http://www.gm.undp.org/content/dam/gambia/docs/NewDocs/NHDR\%20.

Percow, J. (1972), Youths and Political Participation, City of San Diego Community Press, NJ. pp. 97-111.

Sen, Amrtya (1999), Development as Freedom New York: Alfred A. Knopf.

Suleiman A. (2006), The Nigerian Youths in Contemporary Political Development: Relevance, Challenges and Role Expectation A Journal of Constitutional Development Vol. 6 No.4.

Sylvia C and Gareth A. J (2005), "Youth, Gender and Livelihoods in West Africa: Perspectives from Ghana and The Gambia", Children's Geographies, Vol. 3, No. 2, 185-199.

The Gambian Appraisal Report (1999) on Community skills Improvement Project . 
UN (1995) ‘World Programme of Action for Youths to the Year 2000 and Beyond’; New York: UN.

UN (2007) ‘World Youths Report 2007 - Young People’s Transition to Adulthood: Progress and Challenges'; New York: UN.

UN (2010) 'World Youths Report - Youths and Climate Change'; New York, UN Africa Commission (2009) 'Realising the Potential of Africa's Youths'; Copenhagen: Africa Commission.

UN (2015), "Youth Population Trends and Sustainable Development" URL http://www.un.org/esa/socdev/ documents/youth/fact-sheets/YouthPOP.pdf.

UNAIDS. (2011), UNAIDS World AIDS Day Report. Geneva: UNAIDS Secretariat.

UNDP (2014), “The Gambia National Human Development Report 2014: Youth Employment”.

UNECA (UN Economic Commission for Africa). (2005a), 2005 Economic Report: Meeting the Challenges of Unemployment and Poverty in Africa. Addis Ababa: UNECA.

UNECA (UN Economic Commission for Africa). (2005b), Youths, Education, Skills and Employment. Addis Ababa: UNECA.

UNECA (UN Economic Commission for Africa). (2009), African Youths Report 2009: Expanding Opportunities for and with Young People in Africa. Addis Ababa: UNECA.

UNECA (UN Economic Commission for Africa). (2011), African Youths Report 2011: Addressing the Youths Education and Unemployment nexus in the New Global Economy. Addis Ababa: UNECA.

UNESCO (2007), World Youths Report 2007: Young People's Transition to Adulthood-Progress and Challenges. New York: United Nations.

UNHCR, Refugees \& Migrants Sea Arrivals in Europe, December 2016, https://data2. unher.org/en/documents/ download/53447.

United Nations (2018) Youth, Peace building and Regional Solidarity: Lessons from Africa.

World Bank (2007), ‘World Development Report 2007: Development and the Next Generation’; World Bank.

World Bank. (2007a), Africa Development Indicators, 2007. Washington: World Bank.

YBI (Youths Business International). (2008), “Annual Report and Accounts.” Available at http://www. youthsbusiness.org/. Youths and Community Development in Nigeria.

Zedekia S and Michael N M (2016), "Youth and Nation Building In Kenya: Prospects And Challenges" The International Journal of Social Sciences and Humanities Invention Volume 3 issue 6 2016, pp. 2292-2301.

\section{Interviews}

Bintu Camara, Sainey F Manneh, Alli Sanyag, Marian Rebecca Goode, Umukoro Jennifer Ajumebor, Ibrahim Camara, Marian Camara. 